\title{
CONSTRUCTION TECHNOLOGY OF TIMBER-FRAME HOUSES RESISTANT TO DYNAMIC LOADS - STUDY ON MODELS OF EXTERIOR WALLS
}

\author{
Marcin Szczepanski ${ }^{1}$, Wojciech Migda' ${ }^{1}$, Robert Jankowski ${ }^{1}$ \\ 1 Faculty of Civil and Environmental Engineering, Gdansk University of Technology, Narutowicza 11/12 Str., \\ 80-233 Gdansk, Poland, e-mail: marszcze@pg.gda.pl; wmigda@pg.gda.pl; jankowr@pg.gda.pl
}

Received: 2015.10.09

Accepted: 2015.11.14

Published: 2015.12.04

\begin{abstract}
The aim of this paper is to show the numeric representation of experimental studies concerning the behaviour of exterior wall models of a timber-frame house under harmonic loading. A single wall model according to traditional technology of timberframe house walls (filling with mineral wool) was tested. The analysis was conducted for the following frequencies: $0.5 \mathrm{~Hz}, 1.0 \mathrm{~Hz}, 2.0 \mathrm{~Hz}$ and $5.0 \mathrm{~Hz}$ for various values of the specified displacement. A number of hysteresis loops were obtained for each of the tests. Based on them, the damping ratio as well as stiffness were calculated. The skeleton model filled with mineral wool (traditional technology) experienced serious damage under larger displacements. The results of the study have been used to propose a numerical model of wall filled with mineral wool. The proposed numerical model is consistent with the results for the values obtained during the experimental study, which proves the correctness of the adopted solution.
\end{abstract}

Keywords: timber-frame house, exterior wall, numerical model, dynamic loads.

\section{INTRODUCTION}

The preparation of an investment depends mainly on the used technology, where the choice of used materials is very important. In case of small single family houses, where resistance against dynamic loads is required, such as seismic and paraseismic loads (see $[10,11]$ ), one of the most attractive materials is wood. The technology of timber frame buildings is one of the fastest evolving branches in the single family house building sector in Poland and other countries. The fact that such houses are very cost efficient in erection and also in terms of energy efficiency supports this development [5].

Correctly designed structures are marked by good resistance against dynamic loads, such as extreme earthquakes [9]. MFP and OSB/3 waterproof boards are used as wall, slab and roof sheathing. Those boards increase the structural stiffness of the building due to their relative high strength and because of their good resistance against shear forces and fast decay of natural vi- brations, they reduce the forces transmitted to the structure under dynamic constraints $[9,12,13]$.

Based on earthquakes that took place in North America and Japan, it was discovered that timber frame houses are able to withstand those earthquakes with only minor damage [9]. It has been found that a very effective way to dissipate energy under dynamic load is to use plywood as wall sheathing It also increases the stiffness of the structure $[6,7]$. Due to this relative high stiffness, timber frame buildings are resistant to dynamic loads like those transferred by soli e.g. earthquakes and paraseismic loads $[2,8,13]$.

The mechanism, that leads to the destruction of a timber frame building during earthquakes has been observed and could be isolated. It shows that the destruction is related to the intensity of a seismic impact [4]. Besides its stiffness the thermal insulation is also very important for the proper function of the building. The used insulation can have a great influence on the stiffness of the structure or have no influence on the structure, depending on the used insulation method. 


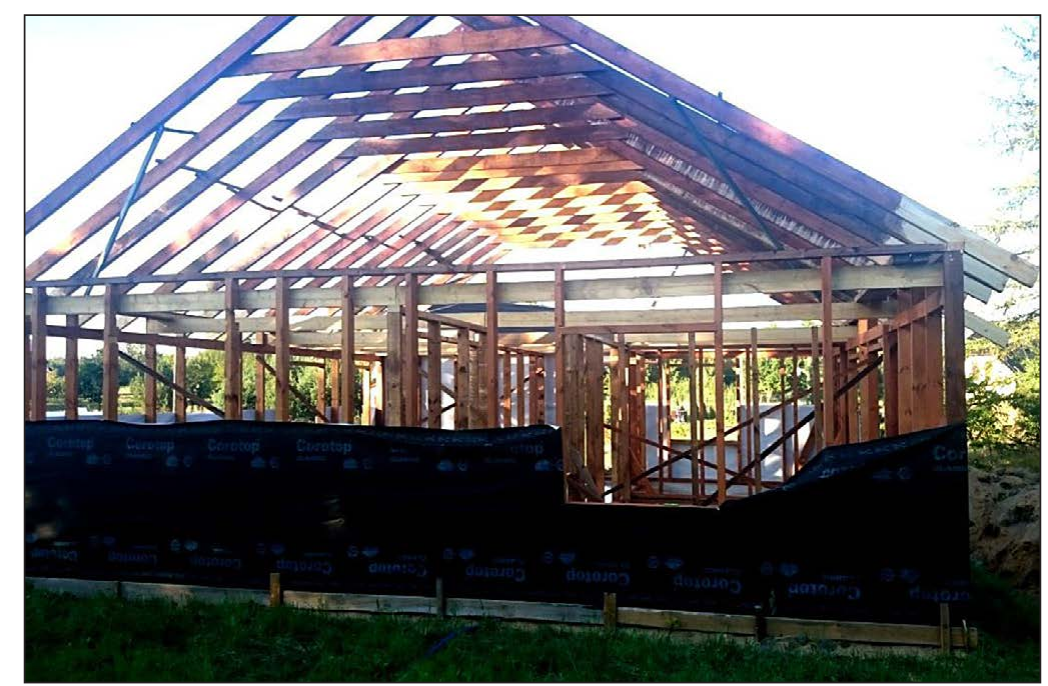

Fig. 1. Example of real size wooden house under construction

The aim of this study is to show the results of experimental tests of a wall panel - in real scale (Fig. 1) - with a traditional rock wool insulation and also the comparison with a numerical model created in the software RFEM, which will be used in the future for a full scale timber frame building in a numerical analysis.

\section{EXPERMINET SETUP}

The used setup was specially designed and constructed for the performed test and was located in the lab of the Faculty of Civil and Environmental Engineering (Fig. 2). The setup was constructed of a steel frame with the dimensions of $300 \mathrm{~cm}$ by $50 \mathrm{~cm}$ that was fixed to the floor and welded mounting brackets with a size of 150 $\mathrm{cm}$ by $60 \mathrm{~cm}$, which enabled the testing of the used specimen - wall panels. On one side of the frame a PARKER actuator with a displacement of $50 \mathrm{~cm}$, a maximum acceleration of $10 \mathrm{~m} / \mathrm{s}^{2}$

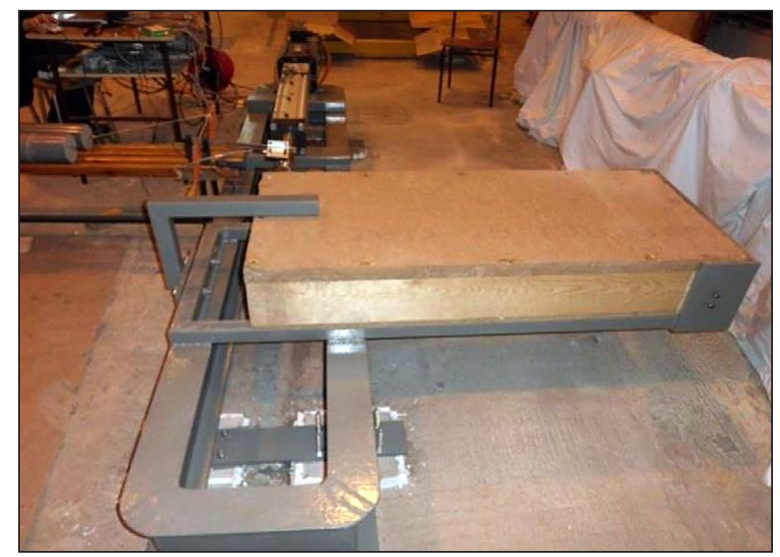

Fig. 2. Experiment setup and a maximum force of $45 \mathrm{kN}$ was installed. Such a setup enabled the test to be of a destructive kind.

For the purpose of this study a typical timber frame house wall panel was built as shown in Figure 3. Using a modulus of $60 \mathrm{~cm}$ for the frame elements, the panel was constructed of

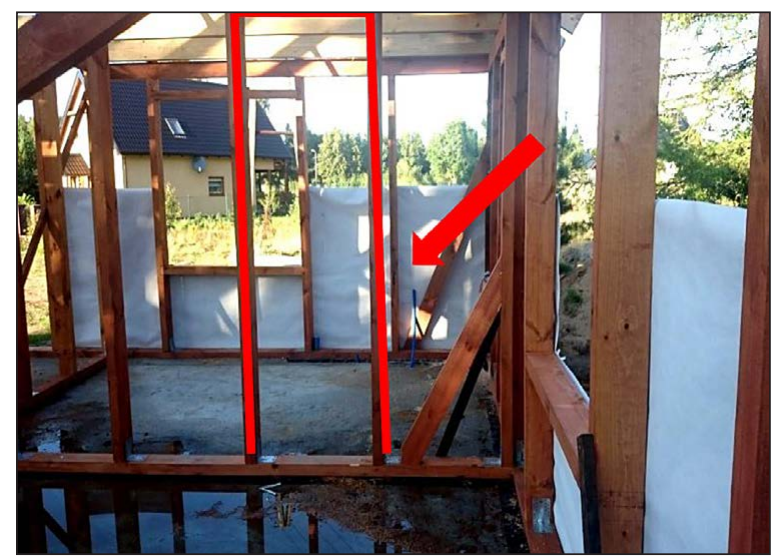

Fig. 3. Wall plane example in real wooden house

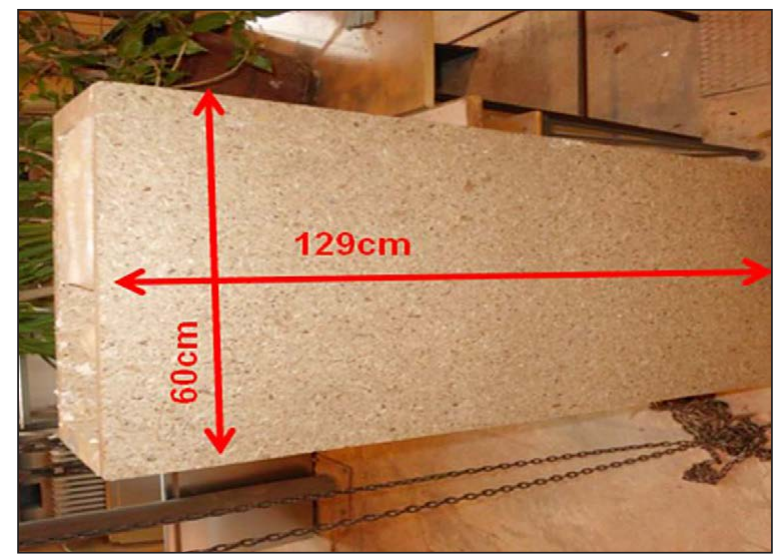

Fig. 4. Wall panel 
wood and in compliance with traditional methods was filled with mineral wool and covered on both sides with OSB3 sheaths. The dimensions of the panel were: length $129 \mathrm{~cm}$ and width $60 \mathrm{~cm}$ (Figure 4). One side of the panel was mounted in a fixed support by using $10 \mathrm{~mm}$ bolts, the other side provided a in plane support in order to disable buckling during the tests (Fig. 5). In the photo below an awall panel of the kind which was used for the experimental study was marked.

\section{ANALYSIS DESCRIPTION}

During the test the specimens were exposed to harmonic loads with the following frequencies: $f=0.5 \mathrm{~Hz} ; f=1.0 \mathrm{~Hz} ; f=2.0 \mathrm{~Hz} ; f=5.0 \mathrm{~Hz}$ and different displacement. During the test the used force was recorded with a force meter KMM40 with a range up to $50 \mathrm{kN}$ as well as the resulting displacement (for the induced dynamic displacement) with a laser meter optoNCDT1302 with a range of $\pm 100 \mathrm{~mm}$ - Figure 5).
During the test traditionally constructed wall panels, with mineral wool filling and OSB3 sheathing were used. The panels were fixed onto one end, while the other end was subjected to displacement from $8 \mathrm{~mm}$ to $75 \mathrm{~mm}$. The displacement had a dynamic character with frequencies from $0.5 \mathrm{~Hz}$ up to $5.0 \mathrm{~Hz}$. Based on the tests hysteresis loops were obtained for every displacement extortion. On this basis the damping ratio was calculated (see [3]). The results were as follows:

a) $f=2 \mathrm{~Hz}$; damping ratio: $17.09 \%$, stiffness: $416.66 \mathrm{kN} / \mathrm{m}$ (Fig. 6);

b) $f=5 \mathrm{~Hz}$; damping ratio: $41.53 \%$, stiffness: $232.55 \mathrm{kN} / \mathrm{m}$ (Fig. 7).

For a wool filled wall panel a frequency of $2 \mathrm{~Hz}$ and a displacement extortion of $28 \mathrm{~mm}$ caused the OSB3 sheathing to break from the wood frame as well as cracking in the connection in the wood frame itself (Fig. 8). For comparison a wall panel that have been filled with PU foam was tested and as can be seen in Figure 8 the element was able to withstand a higher frequency as well as a larger force.

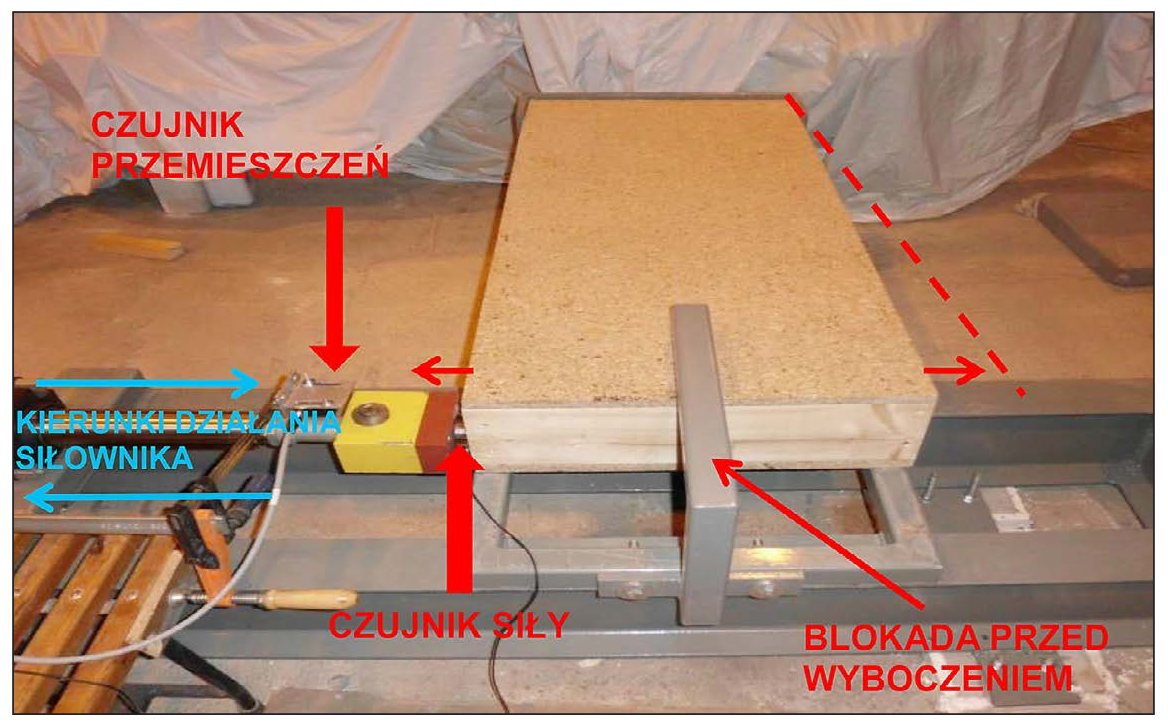

Fig. 5. Experiment setup details

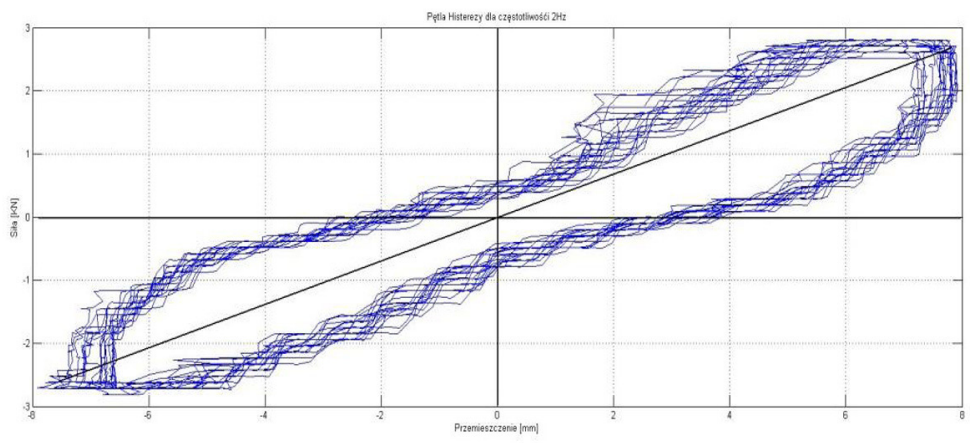

Fig. 6. Hysteresis loop at $2 \mathrm{~Hz}$ (mineral wool filling). 


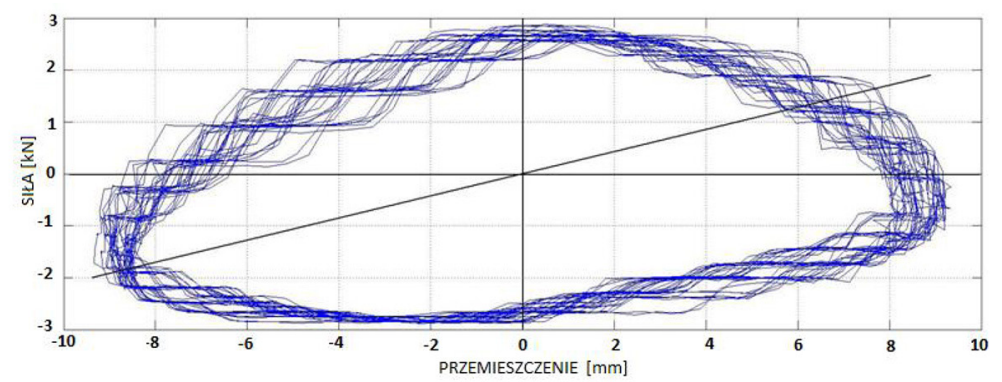

Fig. 7. Hysteresis loop at $5 \mathrm{~Hz}$ (mineral wool filling)

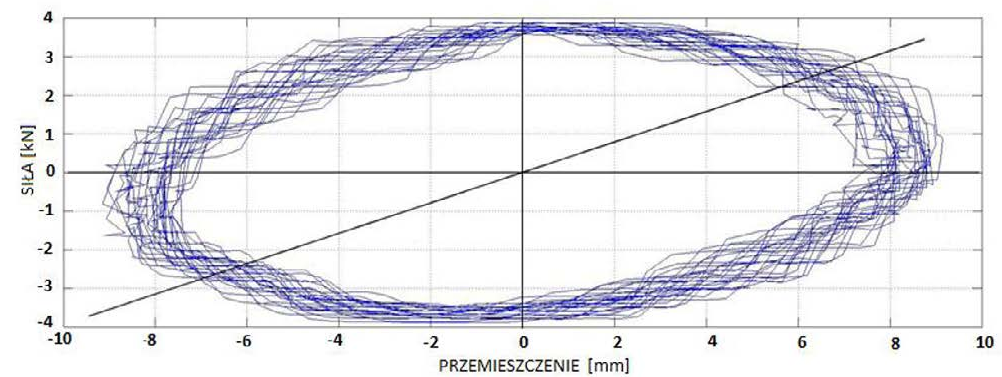

Fig. 8. Hysteresis loop at $5 \mathrm{~Hz}$ (PU foam filling)

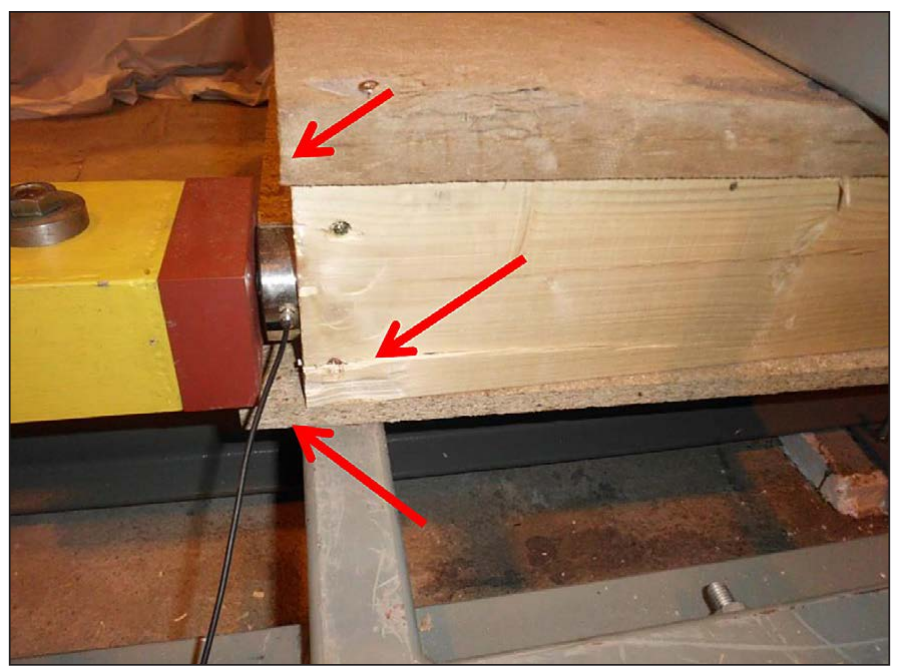

Fig. 9. Element no 1 after the test - cracking in the connection between frame and sheathing

\section{NUMERICAL MODEL OF THE MINERAL WOOD FILLED PANEL}

A numerical model of the tested wood panel was created in the program RFEM. The geometry was kept identically (as for dimension of used elements) and the material characteristics used in the program was chosen accordingly to the parameters of the used materials. Based on the obtained results from the experiment the numerical model was tested and adjusted by changing only the stiffness of the OSB3 sheathing in order to reflect the character of the connection between the frame and sheathing.
In the numerical model shell elements were used with material properties as used for C30 wood, the thickness of the shell elements was 45 $\mathrm{mm}$ for the frame parts and $18 \mathrm{~mm}$ for the OSB3 sheaths and one shell with a thickness of $145 \mathrm{~mm}$ for the mineral wool filling.

The numerical analysis has shown that in terms of displacement under the used load the mineral wool had no effect. It can be assumed that this was due to the fact that the material properties for mineral wool are insignificant in comparison to wood (compressive strength $0.015 \mathrm{MPa}$ and tensile strength $0.010 \mathrm{MPa}$ [14]). Therefore, in the future tests the shell representing the miner- 


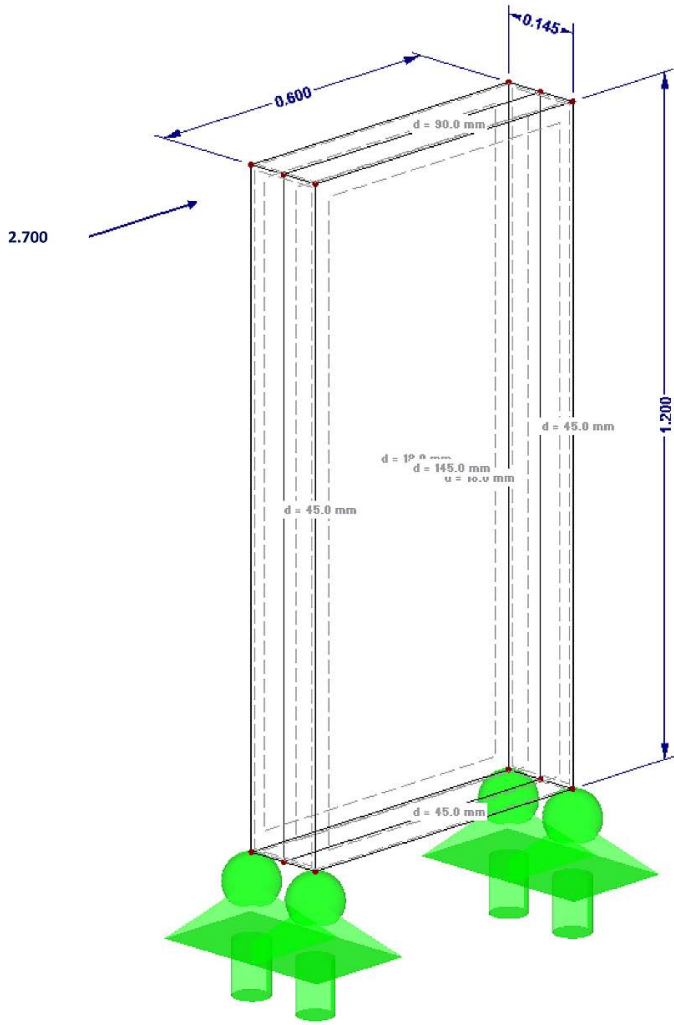

Fig. 10. Numerical wall plane model

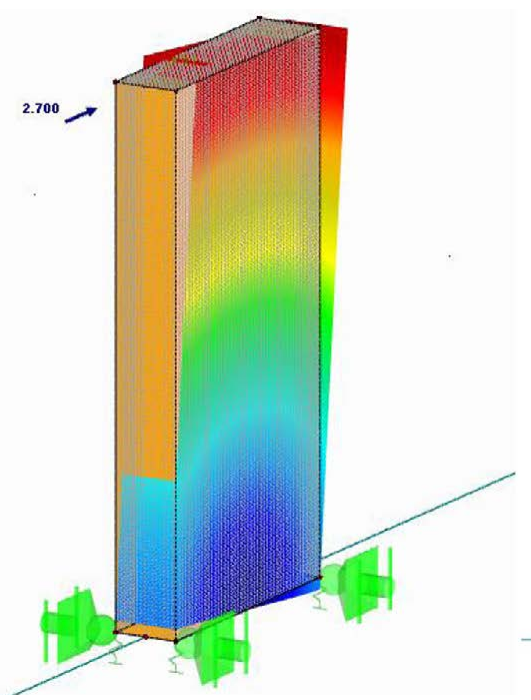

Fig. 12. Deformation of the numerical model al wool will be neglected. The support conditions have been modelled as shown in Fig. 10 - all translations were fixed but all rotations were free, those support conditions have been considered as best corresponding with the experimental setup.

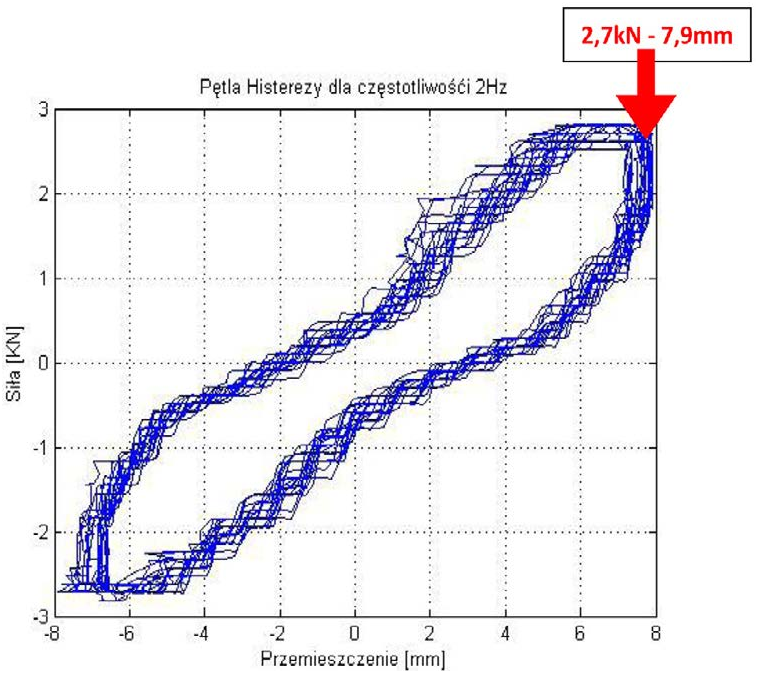

Fig. 11. Hysteresis loop - maximum displacement and corresponding force

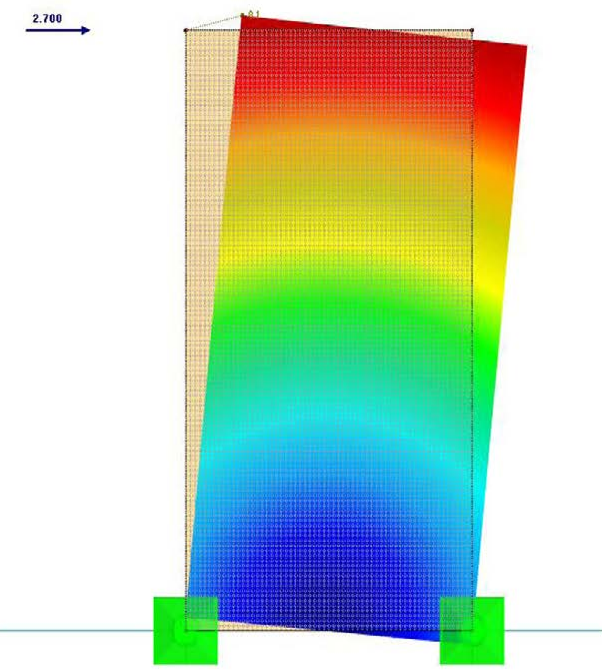

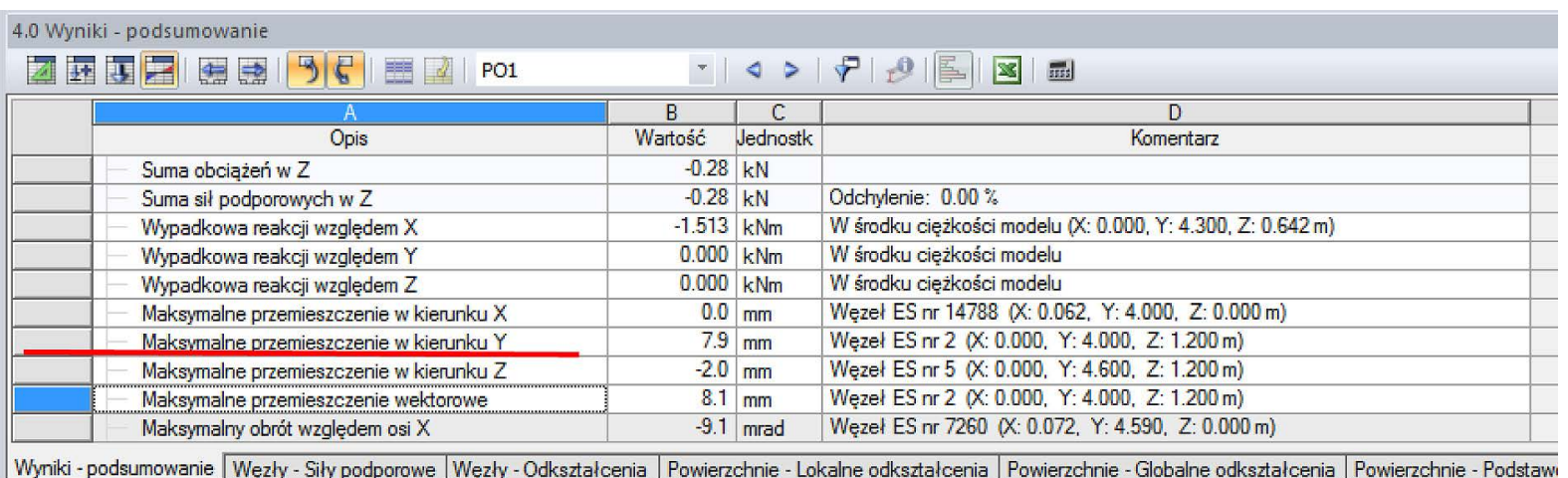

Fig. 13. Results as shown in the software - the same displacement as during experimental test 


\section{NUMERICAL ANALYSIS}

As the next step, the so created numerical model, was tested in order to verify its correctness by exposing the numerical model to the same load as used in the experiment and comparing the resulting displacement (Fig. 11).

For the hysteresis loop received at a frequency of $2 \mathrm{~Hz}$ the resulting force was $2.70 \mathrm{kN}$ and the displacement was $\mathrm{U}=7.9 \mathrm{~mm}$. This force of $2.70 \mathrm{kN}$, as a static force, was used in the numerical model, placed in the same position as in the experiment. The obtained displacement was $\mathrm{U}=7.9 \mathrm{~mm}$, which proved the numerical model correct, for it was exactly the same displacement as in the experiment (Figures 12 and 13).

\section{CONCLUSIONS}

Based on the results of the comparison between the real and numerical model the numerical model has been verified to be correct. The behaviour of the numerical model corresponds perfectly with the real world model. On this basis it can be assumed that not only the material properties and characteristics, but also the support of the numerical model have been created proper. Therefore, the numerical model can be used to investigate dynamic loads - that could not be applied due to the limitations of the experiment setup, but furthermore it offers the possibility to incorporate a whole building as a numerical model and test it under dynamical loads like those generated from earthquakes. Using a numerical model of a whole building it will be possible, after conducting substantial tests with a wall panel filled with PU foam, to evaluate the improvement in resistance against dynamic loads of buildings where PU foam was used instead of mineral wool, which may be exposed to earthquakes.

\section{Acknowlegments}

The authors would like to thank Mr. Maciej Wysokinski from STOLKAL for building the used specimen for the tests and Mr. Bohdan Kowalewski for his help during the tests.

\section{REFERENCES}

1. ECS, Eurocode 8: Design provisions for earthquake resistance of structures. European Committee for Standardization, Brussels, Belgium 1998.

2. Jankowski R., Badania dynamiczne modeli konstrukcji budowlanych na stole wstrząsowym. CzasopismoTechniczne, 2-B, 2007, 29-37.

3. Jankowski R., Nonlinear rate dependent model of high damping rubber bearing. Bulletin of Earthquake Engineering EAEE, 1(3), 2003, 397-403.

4. Kiyono J., Furukawa A., Casuality occurence mechanism in the collapse of timber-frame house during an earthquake. Earthquake Engineering and Structural Dynamics, 33, 2004, 1233-1248.

5. Nitka W., Mój dom z drewna. Centrum Informacyjne Lasów Państwowych, Warszawa 2010.

6. Pei S., Van de Lindt J.W., Coupled shear-bending formulation for seismic analysis of stacked wood shear wall systems. Earthquake Engineering and Structural Dynamics, 38, 2009, 1631-1647.

7. Seo J-M., Choi I-K., Lee J-R., Experimental study on the aseismic capacity of a wooden house using shaking table. Earthquake Engineering and Structural Dynamics, 28, 1999, 1143-1162.

8. Szczepański M., Jankowski R., Experimental dynamic study on a timber-frame house using shaking table. In: Current Scientific Challenges in Concrete and Steel Structures and Concrete Technology. Gdansk University of Technology, Gdańsk 2011, 155-162.

9. Toratti T., Seismic design of timber structures. FEMA, 1994.

10.Zembaty Z, Cholewicki A, Jankowski R., Szulc J., Trzęsienia ziemi 21 września 2004 r. w Polsce północno-wschodniej oraz ich wpływ na obiekty budowlane. Inżynieria i Budownictwo, 1, 2005, 3-9.

11. Zembaty Z, Jankowski R., Cholewicki A, Szulc J., Trzęsienie ziemi 30 listopada 2004 r. na Podhalu oraz jego wpływ na obiekty budowlane. Inżynieria i Budownictwo, 9, 2005, 507-511.

12. Vessby J. Analysis of shear walls for multi-storey timber buildings. Linnaeus University Dissertations No 45, 2011.

13. Zarnic R., Dujic B. Study of rateral resistance of massive X-lam wooden wall system subjected to horizontal loads. Earthquake Engineering on Timber Structures, Portugal 2006. 